\title{
Women in Here, Women in There: Changing Roles and Lives of Women Migrants from Turkey in Italy
}

\author{
Gül İnce Beqo ${ }^{1}$
}

\begin{abstract}
Drawing on interviews with families from Turkey living in Northern Italy and a series of observations, this article focuses on the construction of gender roles through migration experiences and men and women's agency in migration decision-making. Acknowledging the theoretical dichotomy between women being victims or conscious agents in the migratory process, I argue that (1) extended family ties of the country of origin are crucial for comprehending the transformation of gender roles in the migration context and that (2) living away from extended family ties gives women the opportunity to transform the roles attributed to them. Their migration experience seems to give them more possibilities for their needs to be taken into consideration by their husbands in household decision-making. For men, this change is almost never pleasant; in fact, the connotation given to the word 'transformation' is determined by the cultural code that favours the strong gender segmentation. Women like to change while men don't. Such a transformation in family life could also explain the lack of willingness of migrant women to return definitively to Turkey despite all the difficulties faced in Italy.
\end{abstract}

Keywords: Turkey; migration; Italy; gender; social norms; decision-making power.

\section{Introduction}

As with the reasons that push women into migrating, so too do the consequences and difficulties faced in the migration process vary significantly in terms the social roles attributed to them and the structural features of the country of arrival. Previous research has shown that Ethiopian adolescent girls migrating as domestic workers to Middle Eastern countries, like Saudi Arabia, are vulnerable not only due to their sex, but also, due to the lack of legal provision regarding women's rights and gender equality in these countries (Jones et al., 2014). Moreover, in some countries, men also may be exposed to some specific difficulties due to the conditions created by the local labour market structure. For example, male migrants arriving in Italy from Latin America or Eastern European countries face difficulties in finding jobs since the labour market offers women more opportunities than them (Bonizzoni, 2009). Bonizzoni (2017) shows also how gender roles and expectations determine migrants' employer-employee relationships and their work-related legalisation processes in the country of arrival, in this case Italy.

In addition, gender roles and expectations impact significantly on men and women's propensities to migrate. Hoang (2011) finds that Vietnamese women's decision about their own migration is in part constrained, whereby they are forced to negotiate for their own interests in order to preserve the family harmony. The same author (2009) also argues that men and women of the same age are exposed to different expectations about migration decisions; while men are expected

\footnotetext{
${ }^{1}$ Gül İnce Beqo, Lecturer at Catholic University of Milan, Milan, Italy. Email: gul.incebeqo@unicatt.it.
} 


\section{Women in Here, Women in There}

to set up a solid economic foundation, young girls are expected to be good mothers and wives. Such expectations clearly divide the duties such that everyone knows those who will be moving first and those who must follow.

The literature cited above sheds light on what happens in the migration from Turkey to Italy. Low skilled migrants coming from the rural and poor areas of that country experience changes and difficulties, both in relation to the social norms of the country of origin and the structural obstacles that they face in the country of arrival. In Germany, and in many other Western European countries, they are called 'guest workers', while in Italy, not being facilitated by the bilateral agreements, they are "Kurds", "Turks" or "asylum seekers". Italy is a particular destination for migrants arriving from Turkey and several researchers (Schuster, 2005; Çakırer Özservet, 2010; Purkis and Güngör, 2015; Purkis, 2019) have underlined that it was not considered as a country of settlement, but rather, as a transition country where migrants could be helped to travel the Northern European countries. This was the case for many during the 1990s (for the narratives of Kurdish migrants from Turkey to Germany via Italy, see Sirkeci, 2006). However, as discussed in the following paragraphs, after 1997, with the introduction of the Dublin regulation, the purpose of which was to block this unauthorised passage and ensure the reception of asylum seekers in the first country of arrival, many of those arriving from Turkey had to settle in Italy indefinitely.

Moreover, in the absence of bilateral agreements regulating the entrance and settlement of new arrivals, migrants had to rely on the very scarce personal and familiar networks created over the years, both in the pre-migration phase and once it had occurred. Such flow of mostly Kurdish men began at the end of the 1990s through unauthorised channels and continued through family reunification. Once men have adjusted their asylum status, they can invite their spouses or go back to Turkey to get married. Many newlywed brides started to arrive in Italy in the second half of the 2000s. Indeed, the nature of migration from Turkey to Italy, as has happened in other countries, has turned from being primarily a migration of single men to family reunification ${ }^{2}$. While the sociocultural conditions of migrant families in Europe, the transformation of gender roles and expectations as well as the "inter-generational consequences of migration" (Guveli et al. 2016) have been analysed by various scholars (Huls, 2000; Nauck, 1989, 2001; Inowlocki and Lutz, 2000; Phalet and Schönpflug, 2001; Idema and Phalet, 2007; Phalet and Güngör, 2009; Guveli et al., 2016; Apitzsch, 2018) in the European context, research on migration from Turkey to Italy is scarce, especially as regards the role of women and family relationships. This research can, therefore, be seen as an attempt to fill at least a part of the information gaps regarding the position of women in the context of migration, although it focuses only on a specific migration flow: that of poor migrants of rural origin from the east and south of Turkey.

\section{Women and gender in migration}

The interaction between migration and social structures is reciprocal, which means that migration movements are influenced by social rules and norms, whilst these movements also influence these social structures and rules (De Haan, 2000). Existing role models and expectations may be reinforced or transformed by migration and vice versa; migration is shaped around relationships, values and cultural codes. One's perception of rights, possibilities and legitimate behaviour in terms of mobility depends on the views on the different roles for men and women

\footnotetext{
${ }^{2}$ One of the newspapers published on December $29,1997^{2}$ on the arrival of Kurdish asylum seekers indicates that only 11.09 per cent of 835 arrivals were female. However, things have changed over time. According to ISTAT ${ }^{2}$, the number of Turkish residents on the 1st January 2017 indicate that 42.80 per cent of all Turkish residents were female. Such an increase can be interpreted as the fact that the rate of family reunification has been relatively high.
} 
(Hoang, 2009). In line with this assumption, women often face a series of traditional beliefs, which are obstacles their mobility, not to mention a set of normative guidelines concerning "appropriate" and "inappropriate" gender behaviours, which determine women's migration propensities (Zvonkovic et al., 1996; Ellis, 2018). Consequently, while men are able to decide autonomously, migration of women becomes the result of a family strategy (Boyd, 1989). The boundaries between who moves alone or those who follow are not so clear due to the kinship networks, which can be invisible at first sight but may still shape and direct significantly the migration decision (Hondagneu-Sotelo, 1994). In fact, the decision to migrate may seem at first sight to be in the hands of the individual mover, but actually, it is a decision that takes place in reference to the strengths and weaknesses of her or his household, related in turn to three main determinants in the migration decision: age, marital status, and gender roles within the family context (Cohen and Sirkeci, 2011).

Understanding gender is critical in the migration context (Boyd and Grieco, 2003), first, because without an adequate theoretical base it is impossible to understand the conditions under which women migrate $^{3}$ or the high presence of women in certain labour flows. Furthermore, current theories which exclude women from migration studies are not able to illustrate the circumstances that push women into becoming refugees or transnational migrants. Boyd and Grieco (2003) distinguish three main stages where gender roles and inequalities determine the migration process and produce different outcomes for women, the: pre-migration stage, transition across state boundaries and the experience of migrants in the host country. In the pre-migration stage, different factors, such as gender relations and roles or structural characteristics of the home country may determine the ability of women to migrate or the male migration may transform the roles and expectations of left-behind women. Various studies have shown what happens in the family when women are left behind and how gender roles are reorganised. While some of these studies refer to positive effects, in others it is argued that immigration has increased inequality between men and women (e.g. Beqo, 2019; Dudu, 2018; Ellis, 2018).

Hondagneu-Sotelo (1994) contends that Mexican left behind women gain more freedom and power during the absence of their husbands who migrate to the United States and those migrant women who work in the US prefer to continue to live there since they fear becoming dependent on their husband if they ever return. In her research on 44 Mexican migrants of both sexes, HondagneuSotelo (1992) also elicited that once male migration occurs, women, due to low levels of remittance, always take on more responsibility and acquire new skills that may be considered as typically malerelated ones, like employment in the informal sector. On the other hand, during the absence of their wives, men are responsible for the domestic tasks that are typically female-related. Yet, such reversal of gender roles is temporary, for when they unite again, they continue to practise the patriarchal gender division of labour. Conversely, Brouwer and Priester (1983), in their comparative research on Turkish women in Turkey and Amsterdam found that women's freedom in the migration context was decreased, i.e. they were subjected to more control in the Netherlands.

The sources and origins of women's oppression have been deeply analysed within the feminist theory by a specific perspective called intersectionality (Yuval-Davis, 2006; Nash, 2008), which involves analysing how social and cultural categories intertwine (Knudsen, 2006). The application of a feminist perspective to migration research, which highlights women's role in migration

\footnotetext{
${ }^{3}$ According to data from the United Nations Population Division, women comprise slightly less than half of all international migrants, whilst female migrants outnumber males in Europe, Northern America, Oceania, Latin America and the Caribbean (UN International Migration Report, 2017).
} 


\section{Women in Here, Women in There}

(Morokvasic, 1984, 2014), intersectionality ${ }^{4}$ has also started to be used as the main analytical framework of empirical studies on the phenomenon (Lutz et al. 2011).

Women's empowerment as a consequence of migration is another topic that helps us understand the gender dynamics of the migration process. Hugo (2000) argues that the increased empowerment of women depends on many factors, such as the context in which the migration occurs, the female migrant's characteristics and the type of movement. On the other hand, migration becomes a gendered issue through the policies of nation-states towards international immigration. "These policies are frequently conditioned by implicit or explicit assumptions about the status and roles of men and women both within the family and in society. For example, some labour-exporting countries have implemented "conditions" in their policies to protect women from exploitation that effectively prevent them from engaging in labour migration" (Boyd and Grieco, 2003, para. 20). Moreover, they also contend that traditional stereotypical images about the place of women in society can influence the type of work to which women migrants will be directed (ibid). This work, in general, pertains to "female" jobs like domestic service through which in countries like Italy migrant women become a fundamental resource for invisible and informal welfare (Ambrosini, 2013) for families in search of care for their elderly or children.

The gender-based hierarchies that prevail in the host country are as important as those of the country of origin; if the state considers migrant women as dependent even "their rights may become dependent" (Boyd and Grieco, 2003, para. 24). Bonizzoni's research (2007) fits very well with this assumption: migrant women mentioned by Ambrosini (2013) while offering a fundamental economic contribution to Italian society become a problem once they try to overcome the separation from their own family, by applying for family reunification and thus, changing their status.

\section{Research method and participants}

This article is part of a qualitative exploratory study involving 38 in-depth interviews with migrants from Turkey residing in Northern Italy at the time of the study, recruited by a snowballing process. Besides, a series of observations were undertaken during the field research. All the participants are basically from poor and rural backgrounds ${ }^{5}$, hailing from the Eastern and SouthEastern regions of Turkey, whose initial objective was to move to another EU country, without the intention of settling in Italy. Many of them come from Pazarc1k, an ethnically mixed town in the southern part of Kahramanmaraş Province in Turkey.

\section{Challenges and gendered narratives}

My first contacts were women, and initially, they always told me that their husband would not agree to cooperate. Men, in fact, were nearly always less willing to speak, especially about their family relationships. For example, when they were asked about the main attributes of being a good husband, they indicated their uncomfortableness of being questioned by a woman about their manhood (Schwalbe and Wolkomir, 2003) or even wondering whether I doubted their masculinity. In some cases, they interrupted the interview by saying that they had to go to the bathroom or kitchen.

There were also some difficulties in interviewing women. When I started to interview them, I was 31 years old, married and without a child. Such a situation was quite unusual for them since we

\footnotetext{
${ }^{4}$ For a detailed information on intersectionality and its application to migration studies, see Bastia, 2014.

${ }^{5}$ I did not analyse the narratives the migrants that were drawn from the well-educated middle and upper classes hailing from more developed regions of Turkey or those who moved to Italy for business or for education. Hence, given the characteristics of the group under study, the main objectives of this paper is shaped around this small and specific migration group.
} 
were nearly of the same age, though they had become mothers at a very early age. In particular, when I told that we, besides their migration experiences, would also speak about their family practices, they started to ask me questions about why I did not have a baby yet. For them, being a mother meant attaining a higher social status and my childlessness somehow was an obstacle. Nevertheless, one year later, conducting the interviews with women became easier since I was pregnant, and our common experience of motherhood helped them to consider me a woman who could understand their difficulties as a migrant mother.

\section{Notes from the field (1)}

\section{Women in there}

The women who were interviewed can be divided into two categories: those who were already married at the point of migration and those who married after it had occurred. In both cases, as the interviews suggest, participants' migration to Italy was a typical example of male migration, whereby the men migrated first and instigated the family reunification later.

Canan was 18 years old when she got married in 1991 in Pazarcik. When her husband decided to come in Italy in 2000 due to the political and economic problems, she was already a mother-ofthree just having moved to the city centre from the small village where she had been living with her husband. The migration of her husband meant having to go back to the village, since living alone in the absence of husband is not considered correct behaviour, So, as with all the other women interviewed, she moved to her in-laws' house while waiting for family reunification. While Canan's case can be considered as an exception since she reported that, they "chose to come here", it is still not very different from those of others, if one probe past the initial perception. Canan recounts that, due to political and financial problems they decided to migrate, i.e. it was a joint decision, but she had not agreed about moving separately. Nevertheless, her resistance about not migrating separately did not help in any decisive way.

When Derya, a 27-year-old young woman, became aware in 2010 that her paternal cousin once removed wanted to marry her, she initially did not accept because he was a gurbetçi ${ }^{6}$ as well as being a haughty and rude person to her mind. Another reason why she refused to marry him was that doing so would also have been accepting that she would have to migrate. Things changed when they met, she decided to marry him and agreed implicitly to migrate as well.

Nermin's case is similar to that of Derya. She met her future husband in 2003 at the recommendation of his mother. When got to know that the man who wanted to marry her lived in Italy and that he would subsequently want to bring her too, she completely disagreed since migrating to Italy and leaving her parents and siblings behind filled her with much fear:

"My husband was already living here. He came to Turkey for a holiday and his mother wanted him to marry. (...) I had learnt that he was living abroad, and I rejected him immediately without even talking to him in person. I am very attached to my family, siblings... I thought it would be too much for me to live abroad" (Nermin, 32, F).

The reason why she accepted marrying him was that:

"To be honest, if it wasn't him, then someone else would have taken me abroad"

${ }^{6}$ Someone who lives and works in another country. 


\section{Women in Here, Women in There}

The research results indicate that the reason why men migrate first is that they arrive in Europe in unauthorised ways and according to them, such conditions are not suitable for women. Hence, families in which women are highly dependent on males, the dominant gender beliefs about men as the breadwinner and women as the wife and mother influence the decision about who in the family should migrate first.

It is also because, as Kenan underlines, men's migrating first is a deep-rooted tradition within the culture:

"A: In our culture, men migrate first. It does not matter if he is married or not; he migrates first. We do not let women come to Europe alone. Never. (Kenan, 41, M).

\section{Notes from the field (2)}

\section{Women in here}

As above explained, the women interviewed were basically poor and rural-origin migrants, hailing from places where the traditional gender roles and patriarchal family dynamics are strongly present. They migrated to a society, in this case to Northern Italy where there is a more egalitarian relationship between men and women. To understand how this movement had affected their state of being woman, I asked them the differences or the similarities of being woman/wife there (Turkey) and here (Italy).

Aycan told me several times that she initially had (and still has) many difficulties in Italy due to the fact that she is not fluent in Italian. But she was very glad to live abroad, because of the possibility to manage her family life as she wanted. That is, without the interference of in-laws in her marriage, she had perceived that she would be able to live according to her wishes. For Aycan, living independently from the extended family affected positively the husband-wife relations. The statement below proves that, in the absence of extended family ties, not only is the relationship between husband and wife improved, but women also have greater freedom of movement in their home-based lives.

"There is nobody interfering with you here. In Turkey, your mother-in-law or sister-in-law interfere. Here, you are more interlocked with your husband. There is nobody to destroy your relationship. (...) You can behave however you wish. I return home at five o'clock in the evening when I want to go somewhere. In Turkey, my motherin-law would interfere." (Aycan, 32, F).

As well as being more independent, some female participants highlighted also the improvement of their relationship with their husband in the new social environment. To be taken into consideration by one's husband and spend time with him was one of the most reported upon determinants to account for such improvement.

"(With your husband) you get more connected in a foreign land. Here, I need him, and he needs me." (Feride, 33, F).

Canan came to Italy after living with her in-laws for six years during the absence of her husband. Despite the fact that they did not have much trouble with the in-laws during their cohabitation, it was very difficult living by the rules of another home and thinking about how they would react to something that she would do: 
Our marriage would be maybe more difficult if we lived in Turkey. Here, we are more tied to each other. (...) In Turkey, if couples get on really well with each other, people start to say that he is a henpecked husband. Here, we get permission from each other. Here, we are more bound to each other (...)" (Canan, 43, F).

Cemile also considered migration as providing the opportunity to develop different attitudes to their marriage. For her, to be away from the extended family was a chance to "exist" for her husband. Living alone with no friends or family makes her the only person with whom her husband could have a relationship. As underlined, such a relationship is not simply based on need, but rather, gives her the possibility to be taken into consideration by her husband.

"I think it must be different here than in Turkey. Here, it must be better. After all, we only have each other. Back there, it's a big family; here it's just us. You and me... We need to support each other. Nobody else will. He needs me... Or better... He takes me into consideration. I exist here." (Cemile, 32, F).

Similarly to what happens in the domestic sphere as regards the relationship with their husbands, some changes occur as well in the public space. The example of Saliha (37) suggests that living in Italy gives them the possibility to do things that cannot be easily done in their homelands:

"A: The best part is (of living in Italy), you are freer here. Not like in Turkey. You are not limited here. There everyone knows what you do where you go. Here is different. You can go anywhere and do anything you want as a woman. The worst part is homesickness, nothing else." (Saliha, 31, F).

Cemile also highlighted the possibility of being freer outside of the home as a woman. She had noticed that especially for women whose husbands are far away from home to have a social life outside of the home is quite impossible, since they might be considered responsible for the things they experienced, like being catcalled or sexually harassed.

"I don't think there's much of a life there (...) if I was to go from one place to another, as a woman, all by myself they'd ask: 'where's this woman coming from?' They would catcall ... (It is difficult.) Both as a woman and a girl. For example, if your man's not home and you are coming home from somewhere, they will ask you, 'where have you been, what did you do? Where's your daughter-in-law coming from at this hour!' Then you will have no peace at home. But here, If I were to go out on my own, nobody says anything (...) It is more comfortable here. (...)" (Cemile, 32, F).

Away from the social pressures that they experience in their homeland, women's use of public spaces increases in the receiving countries, even though only in a limited way.

The other side of the coin tells another story. Contrary to what was said by other participants, Meral highlighted that in some small cities in Italy, like Imperia, Turkish women and young girls are extremely controlled by their husband and/or brothers. They are rarely allowed to go outside or participate in religious activities, even if they are directed only at women. Meral argued that these familial controls over women increase in the migration context because men are convinced that Europe does not favour patriarchal family life and frequent contact with Italians could create conflict between their family model and that of the host society. There are two main reasons why such restriction occurs, especially in places Imperia, a small tourist town in the Liguria region. First, it is the only city in Italy situated on the coast where there are a high number of Turkish immigrants. 


\section{Women in Here, Women in There}

So, considering that life out of the home in a coastal city is much livelier than in a landlocked one, men may justify their restrictions on women, referring to this type of life as a danger to their traditional family pattern. The second reason may be the size of the city: when it is a small city and everyone knows everyone else, men can feel more pressured fall in line with the moral behaviour of the traditional Turkish family.

When I asked Kenan if Turkish immigrants in Italy, after 50 years, would have the same problems as those who live in Germany, he replied:

"I don't think that we will have the same problems of Germany. We have a big advantage. We all live in the same region. Since everyone knows each other, we think twice before doing something wrong (...) So, we think that if we do something wrong everyone knows it, so we control ourselves." (Kenan, 41, M).

As can be seen, the perception of distance is highly gendered. When living together and knowing each other is mentioned by a man, it becomes a positive control mechanism on the migrant community's, while when referred to by a woman, like in the case of Meral, it can be seen as a reason for further pressure on women.

Some women think that if they were a man, their migration experiences would be different. Women who I interviewed underlined several times that "for a woman, home-life is important" (Selma, 42, F), but such home-life is considered also seen as an impediment to participation in the new social life in which they find themselves. They told me that, if they were a man - or an Italian woman - they would have more possibilities to enjoy their life and learn the language since they would have more time out of the home.

"A: You think you'd be more comfortable if you were a man?

B: (giggles) Well, yeah. Men are free, not like women. If I were an Italian woman, I would be free but... Who wouldn't want to travel around, see things, get enlightened...? Everybody likes to have fun. Everyone. But it's different when you're a woman" (Cemile, $32, F)$.

"If I were a man, I wouldn't spend so much time at home, I would have my friends and I would have the opportunity to learn the language. Now, I spend most of my time with my children, so I cannot learn anything." (Saliha, 31, F).

\section{Conclusion}

In this paper, I have examined the way migration experience shapes and determines the lives of first-generation women migrants living in Italy in terms of gender roles and expectations. In order to comprehend the "social and cultural processes that determine how gender relations and expectations evolve during the process of migration" (Parrado and Flippen, 2005, p. 606), both the initial and after-migration phases have been analysed.

The Turkish community in Italy differs from the other Turkish communities in Europe where Turkish migration is a solid phenomenon. While third and fourth generations form a huge chunk of the Turkish diaspora in Germany, in Italy, the first generation of Turkish immigrants is still just middle aged, and the second, still relatively young. Thus, it is quite a young community where extended family ties rarely exist. This means that, for women, migration not only means moving from their country of birth to Italy but also moving away from an extended household - living with in-laws - to a nuclear family form. In patriarchal family models, the autonomy of men is consolidated within extended family relationships. When these relationships are not present men 
struggle to maintain their decision-making capacity. In the migratory context, such a burden can manifest itself as greater pressure on women, while sometimes it can deeply transform the roles and expectations of members within the nuclear family.

When we analyse the roots of the oppression towards women, the concept of intersectionality (Yuval-Davis, 2006; Nash, 2008) and its application to the empirical studies on migration (Lutz et al. 2011) may help us to conceptualise better the complex picture of the production and reproduction process of this oppression. Why did some participants underline that their life would be quite easier, both in the family context and in the public sphere, not only if they were men but also if they were Italian women? In the light of the concept of intersection of gender with other forms of social identity, the problem of inequality stems not just from being women, but from being Turkish women and from the cultural codes attributed to them.

However, in the light of the way Inowlocki and Lutz (2000) define agency, as an acknowledgement of how women deal with difficult conditions and not an idealisation of female migrants' freedom of action, most of the women in this research are following the example of Hülya (Inowlocki and Lutz, 2000), i.e. they prefer to change to confinement despite all the adverse and difficult social conditions. In the awareness of different possibilities, they are trying to produce new relational forms rather than reproduce those already existing.

\section{References}

Ambrosini, M., 2013. Irregular migration and invisible welfare. Basingstoke: Palgrave Macmillan. https://doi.org/10.1057/9781137314321

Apitzsch, U. (2018) Reversal of the Gender Order? Male Marriage Migration to Germany by Turkish Men: New Forms of Gendered Transnationalization of Migrant Offsprings in Germany in Crespi et al. (eds.), Making Multicultural Families in Europe, Palgrave Macmillan Studies in Family and Intimate Life, pp: 55-70. https://doi.org/10.1007/9783-319-59755-3 4

Armelloni, M. (2008). "Comunità e ambiguità: Il caso dei rifugiati politici kurdi" in M. Van Aken (eds.). Milano rifugio. Napoli, Carta Editore, 163-179.

Beqo, G. I. (2019). Hadi Çav! Türkiye’den İtalya’ya Göç ve Göçmenlerin Aile İlişkileri. Göç Dergisi, 6(1), 73-96. https://doi.org/10.33182/gd.v6i1.625

Bever, S. W. (2002). "Migration and the transformation of gender roles and hierarchies in Yucatan", Urban Anthropology and Studies of Cultural Systems and World Economic Development, 31 (2): 199-230.

Bonizzoni, P. (2007). Famiglie transnazionali e ricongiunte: per un approfondi-mento nello studio delle famiglie migranti, Mondi migranti 2: 91-108.

Bonizzoni, P. (2009). Living together again: families surviving Italian immigration policies, International Review of Sociology, 19 (1) pp: 83-10. https://doi.org/10.1080/03906700802613954

Bonizzoni, P. (2017). The shifting boundaries of (un)documentedness: a gendered understanding of migrants' employment-based legalization pathways in Italy, Ethnic and Racial Studies, 40: (10), pp: 1643-1662. https://doi.org/10.1080/01419870.2016.1229488

Boyd M. (1989), Family and Personal Networks in International Migration: Recent Developments and New Agendas. International Migration Review, 23 (3): 638-670. https://doi.org/10.1177/019791838902300313

Boyd, M.; Grieco, E. M., (2003). Women and migration: incorporating gender into international migration theory. Retrieved from Migration Policy Institute website: http://www.migrationpolicy.org/article/women-and-migrationincorporating-gender-international-migration-theory

Brouwer L., Priester M. (1983) Living in Between: Turkish Women in Their Homelands and in the Netherlands. In One way ticket: Migration and Female Labor, ed. Annie Phizacklea p.p. 113-129. Boston: Routledge and Kegan Paul.

Çakirer, Y., (2010) Göç Trafiğinde Araftakiler: İtalya'daki Türkler, Kitap Bölümü: Yurtdışındaki Türkler: 50. Yılında Göç ve Uyum (Ed. M. Murat Erdoğan), 2010: 763-768.

Cohen, J. H. and Sirkeci, I. (2011). Cultures of migration. The global nature of contemporary mobility. University of Texas Press, Austin. https://doi.org/10.4337/9781784714123

Connelly, R., Roberts, K. and Zheng, Z. (2010.) The impact of circular migration on the position of married women in rural China, Feminist Economics, 16, (1): 3-41. https://doi.org/10.1080/13545700903382752 


\section{Women in Here, Women in There}

De Haan, A. (2000). Migrants, Livelihoods, and Rights: The Relevance of Migration in Development Policies, Social Development Working Paper. 4: 1-39.

Dudek, A. (2017, February 10). Religious diversity and the Alevi struggle for equality in Turkey. Retrieved from: https://www.forbes.com/sites/realspin/2017/02/10/religious-diversity-and-the-alevi-struggle-for-equality-inturkey/\#f0f3a0c6d03a

Dudu, S. (2018). International Migration to Seville. Border Crossing, 8(2), 355-378. https://doi.org/10.33182/bc.v8i2.597

Ellis, B. A. (2018). Trapped on Love Boat: Middling and Transient Entrapment among Balkan Seafarers in the Cruise Industry. Border Crossing, 8(2), 393-408. https://doi.org/10.33182/bc.v8i2.602

Güveli, A., Ganzeboom, H., Platt L., Bernhard, N., Baykara-Krumme, H., Eroglu, S., Bayrakdar, S., Sozeri, E., Spierings, N. (2016). Intergenerational consequences of migration: socio-economic, family and cultural patterns of stability and change in Turkey and Europe. Palgrave Macmillan. https://doi.org/10.1057/9781137501424

Hoang, A. L. (2009). Gender identity and agency in migration decision-making: Evidence from Vietnam, Asia Research Institute, Working Paper Series, n. 115.

Hoang, A. L. (2011). Gender identity and agency in migration decision-making: Evidence from Vietnam, Journal of Ethnic and Migration Studies, 37, (9): 1441-1457. https://doi.org/10.1080/1369183X.2011.623618

Hondagneu-Sotelo P. (1992) Overcoming patriarchal constraints: the reconstruction of gender relations among Mexican immigrant women and men. Gender and Society. 1992;6(3):393-415. https://doi.org/10.1177/089124392006003004

Hondagneu-Sotelo P. (1994) Gendered Transitions: Mexican Experiences of Immigration, Berkeley and Los Angeles, CA, University of California Press.

Hugo, G. (2000). Migration and women empowerment, in B. Harriet Presser and G. Sen (eds.). Women Empowerment and Demographic Process, Oxford University Press, 287-317.

Huls, E. (2000). Power in Turkish migrant families. Discourse and Society, (11)3, pp. 345-372. Retrieved from: http://www.jstor.org/stable/42888321?seq=1\#page_scan_tab_contents https://doi.org/10.1177/0957926500011003004

Idema H., Phalet K. (2007) Transmission of Gender Role-Values in Turkish-German Migrant Families: The role of gender, intergenerational and intercultural relations. In Zeitschrift für Familienforschung 19 (2007), 1, p.p. 71-105. Retrieved from: http://www.ssoar.info/ssoar/bitstream/handle/document/5806/ssoar-zff-2007-h_1-idema_et_altransmission_of_gender-role_values_in.pdf?sequence $=1$

Inowlocki, I., and Lutz, H. (2000). The 'biographical work' of a Turkish migrant woman in Germany. European Journal of Women's Studies, 7(3), 301-320. https://doi.org/10.1177/135050680000700305

Istat (The Italian National Institute of Statistics) (2016). Indicatori Demografici, Istat.

Jones, N., Presler-Marshall, E., Tefera, B., Emirie, G., Gebre, B. and Gezahegne, K. (2014) Rethinking Girls on the Move: The Intersection of Poverty, Exploitation and Violence Experienced by Ethiopian Adolescents Involved in the Middle East 'Maid Trade'. London: Overseas Development Institute.

Lutz, H., Herrera Vivar, M. T., Supik, L. (2011). Framing intersectionality: debates on a multi-faced concept in gender studies. Farnham: Ashgate.

Morokvašić, M., (1984). Birds of passage are also women. International Migration Review, 18(4), p.p. 886-907. https://doi.org/10.1177/019791838401800402

Morokvašić, M., (2014). Gendering Migration, Migracijske i Etničke Teme, 31 (3): 355-378. https://doi.org/10.11567/met.30.3.4

Nash, J. (2008). Re-thinking intersectionality. Feminist review, (89) pp. 1-15. https://doi.org/10.1057/fr.2008.4

Nauck, B. (1989). Intergenerational relationships in families from Turkey and Germany. European Sociological Review (5)3, pp.251-274. https://doi.org/10.1093/oxfordjournals.esr.a036525

Nauck, B. (2001). Intercultural contact and intergenerational transmission in immigrant families. Journal of CrossCultural Psychology, (32)2, pp. 159-173. https://doi.org/10.1177/0022022101032002004

Parrado, E.A. and Flippen, C.A. (2005). Migration and gender among Mexican women, American Sociological Review, 70 (4): 606-32. https://doi.org/10.1177/000312240507000404

Phalet, K., Schönpflug, U. (2001). Intergenerational transmission of collectivism and achievement values in two acculturation contexts: the case of Turkish families in Germany and Turkish and Moroccan families in the Netherlands. Journal of Cross-Cultural Psychology, (32) pp. 186-201. https://doi.org/10.1177/0022022101032002006

Phalet K., Güngör D. (2009) Cultural Continuity and Discontinuity in Turkish Immigrant Families: Extending the model of family change in Bekman S., Aksu-Koc A., editors. Perspectives of Human Development, Family and Culture. Cambridge: Cambridge University Press, p.p. 241-262. https://doi.org/10.1017/CBO9780511720437.018

Purkis, S. and Güngör, F. (2015). Experiences of migrants from Turkey in Milan/Italy, İstanbul Üniversitesi Siyasal Bilgiler Fakültesi Dergisi, 3: 1-29. Retrieved from http://dergipark.gov.tr/iusiyasal/issue/24500/259673. 
Purkis, S. (2019). Invisible Borders of the City for the Migrant Women from Turkey: Gendered Use of Urban Space and Place Making in Cinisello-Milan, International Migration\&Integration. 20: 261-278. https://doi.org/10.1007/s12134018-0600-2

Schuster, L. (2005). The continuing mobility of migrants in Italy: shifting between statuses and places, Journal of Ethnic and Migration Studies, 31 (4): 757-774. https://doi.org/10.1080/13691830500109993

Schwalbe, M. L. and Wolkomir, M. (2003). Interviewing men, in J. A. Holstein and Gubrium J. F. (eds.). Inside Interviewing: New Lenses, New Concerns. Sage Publications, 55-71.

Sirkeci, I. (2006). The Environment of Insecurity in Turkey and the Emigration of Turkish Kurds to Germany. New York: Edwin Mellen Press.

Stefon, M. (eds.). (2010). Islamic beliefs and practices, Britannica Educational Publishing.

UN International Report, 2015. Retrieved from: https:/www.un.org/en/development/desa/population/migration/ publications/migrationreport/docs/MigrationReport2015_Highlights.pdf

Yuval-Davis, N. (2006). Intersectionality and feminist politics. European Journal of Women's Studies, (13), pp. 193-209. https://doi.org/10.1177/1350506806065752

Zvonkovic, A., Greaves, K., Schmiege, C., Hall, L. (1996). The marital construction of gender through work and family decisions: A qualitative analysis, Journal of Marriage and the Family, 58: 91-100. https://doi.org/10.2307/353379 


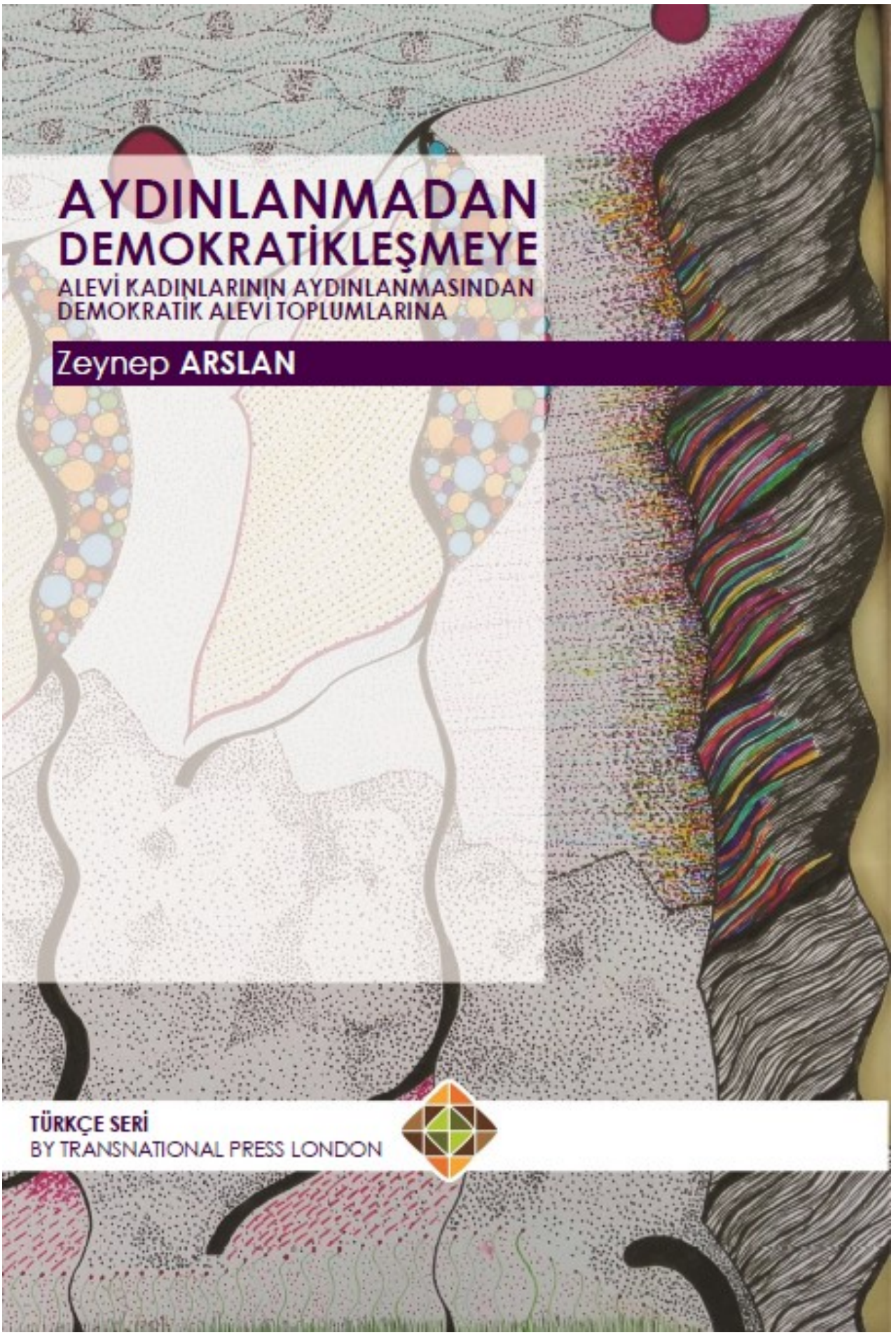

https://tplondon.com 